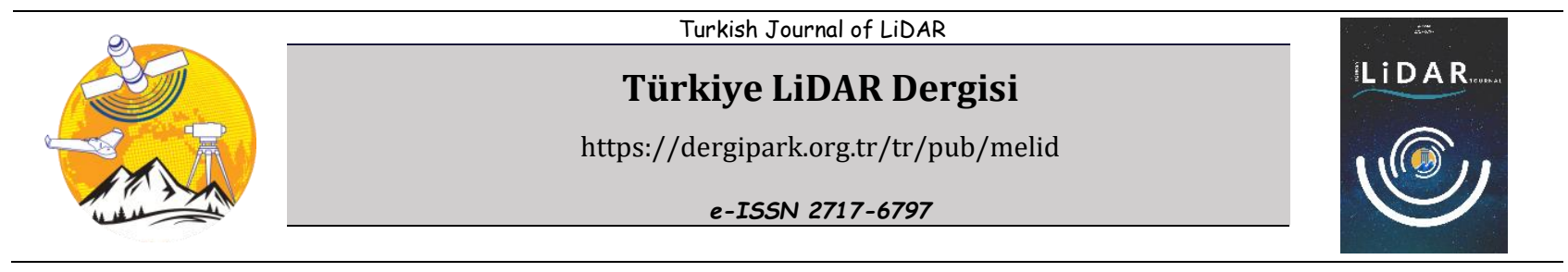

\title{
Indoor Mapping and Positioning Applications of Hand-Held LiDAR Simultaneous Localization and Mapping (SLAM) Systems
}

\author{
Mustafa Zeybek*1 \\ ${ }^{1}$ Selçuk University, Güneysınır Higher School of Vocational Education, Arhitecture and Urban Planning Department, Güneysınır, \\ Konya/Türkiye.
}

\author{
Keywords \\ Point cloud \\ LiDAR \\ Hand-held laser scanner \\ Indoor mapping \\ Building plan extraction \\ Building Information \\ Modeling (BIM)
}

\begin{abstract}
Indoor mobile laser scanning (MLS) systems, based on the principles of simultaneous localization and mapping (SLAM), have become an approved method in recent years to obtain indoor environment data. 2D and 3D laser scanning systems based on SLAM algorithms have now become portable systems hand-held and on the back. The SLAM approach instantly determines the necessary positioning and mapping parameters by using the sensors' data and thus produces data representing the environment in 2D or 3D with point clouds. 3D and 2D building plans provide reference base maps for indoor location and positioning. These data are also of high importance for architectural surveys and restoration works, and indoor design. However, the SLAM process generating duplicated and noisy point clouds causes challenges in defining the characteristics of linear edges and planes. In this study, preliminary study results of the methodology applied for the semi-automatic drawing of a building plan from a building section obtained from SLAM data are presented. With this proposed method, it is provided to facilitate indoor drawings and extract 2D planar and geometric information from the complexity of 3D point clouds. Since the proposed study is becoming an adaptive methodology, it is a method capable of development, and it is thought that performance criteria can be increased.
\end{abstract}

\section{El-tipi LiDAR Eş Zamanlı Konumlama ve Haritalama (SLAM) Sistemlerinin İç Mekân Haritalama ve Konumlandırma Amaçlı Uygulamaları}

\author{
Anahtar Kelimeler \\ Nokta bulutu \\ LiDAR \\ El-tipi lazer tarayıcı \\ İç mekan haritalama \\ Bina planı çıkarımı \\ Bina bilgi modeli
}

\begin{abstract}
ÖZ
Eşzamanlı konumlandırma ve haritalama (SLAM) prensiplerine dayanan iç mekân mobil lazer tarama (MLS) sistemleri, iç mekan ortam verilerinin elde edilmesinde son yıllarda tercih edilen bir yöntem haline gelmiștir. SLAM algoritmaları temelli 2B ve 3B lazer tarama sistemleri günümüzde artık elde ve sırtta taşınabilir portatif bir sistem halini almıștır. SLAM yaklaşımı, sensörlerden gelen verileri kullanarak gerekli konumlandırma ve haritalama amaçlı parametreleri anlık olarak çözüme ulaştırmaktadır ve bu sayede ortamı $2 \mathrm{~B}$ veya $3 \mathrm{~B}$ olarak nokta bulutlarıyla temsil eden verileri üretmektedir. 3B ve 2B bina planları, iç mekân konumlandırma amaçlı referans altlık haritalar sunmaktadır. Üretilen bu veriler aynı zamanda mimari rölöve ve yenileme çalışmaları için ve iç mekan tasarımlarında da büyük bir öneme sahiptir. Ancak SLAM sürecinin tekrarlı ve gürültülü nokta bulutlarını üretmesi doğrusal hatların ve düzlemlerin karakteristiğinin tanımlanmasında zorluklara neden olmaktadır. Bu çalışmada, SLAM verilerinden elde edilmiş bir binanın yarı otomatik olarak bir kesit üzerinden bina planının çıkarımı için uygulanan metodolojinin ön çalışma sonuçları sunulmuştur. Önerilen bu yöntem ile iç mekan çizimlerinin kolaylaştırılması ve 3B nokta bulutlarının karmaşașından 2B düzlemsel ve geometrik bilgilerin çıkarımının kolaylaştırılması sağlanmıştır. Önerilen çalışma adaptif bir metodolojiye açık olduğu için geliştirilmeye açık bir yöntemdir ve performans kriterlerinin artırllabileceği düşünülmektedir.
\end{abstract}




\section{INTRODUCTION}

Drawing out the plans of closed spaces and developing interior space designs are among the main mapping issues from the past to the present (Sirmacek et al., 2016). The existence of maps and plans, especially in the renewal stages of buildings with architectural importance, makes these processes easier to interpret from an architectural point of view. Many studies for geomatics are pioneering these studies today. Building plans and building areas constitute an important subject for many disciplines (Velas et al., 2019).

The development of total station devices with laser signals constitutes an important step in measuring and mapping architectural structures for similar purposes. Advances in technology and physical science enabled the spread of terrestrial laser scanning systems in the early 2000s (Gopi et al., 2018). However, these measurement practices were carried out with multiple sessions and were still insufficient for the surveyors, which led to a new search, and mobile laser scanning systems were developed. These systems have provided solutions to measurement and documentation processes in areas where measurement areas are complex, access is reduced, or the possibility of applying terrestrial laser scanning measurement procedures is limited (Yadav \& Singh, 2018).

In the last decade, mobile laser scanning or mobile LiDAR (MLS) systems installed on the vehicle were used for topographic and corridor mapping purposes, but their dimensions did not allow the mapping of indoor spaces (Karasaka, 2012). The development of hand-held or wearable laser scanning systems has led to the elimination of such limitations. In this way, portable systems are important advantages to be adapted with mapping or measurement techniques to provide detailed and geometric information for 2D / 3D data collection, versatile to complex and confined spaces, and reconstruct different environments that respond to common purposes.

Hand-held LiDAR technologies, an innovative approach in modern construction industries, are a system that saves time and money in the mapping manner of the entire field, allows safe observation and investigation, and has the potential to facilitate building information model activities. However, today, the slow evolution of the institutions and organizations dealing with the complex current situation of the buildings and the outdoor layout plans against these developing technologies prevents the widespread use of LiDAR systems. Besides, MLS mapping systems have applications in different fields. These systems make significant contributions to the 3D mapping of large and complex areas with effective and practical, high-performance near/mid/longrange laser devices. However, the expensive and complex technology of MLSs, different equipment, and accessories are also among the factors limiting their use. The complexity of these integrated systems has supported developing technologies that are easier to apply in indoor mapping and portability that better reach the needs.

In recent research, developments in integrated features similar to MLS in measuring applications performed at close range, mainly portable solutions, have been produced. Hand-held or back-mounted devices have thus become available for complex indoor mapping, industrial buildings, forest inventory extraction, tunnel, mine, volume calculations, and the production of 3D spatial models of the cave and its surroundings (Bauwens et al., 2016; James \& Quinton, 2014; Sammartano \& Spanò, 2018).

As a result, very limited research has highlighted the potential applications of hand-held LiDARs in archeology, architecture, and civil engineering, and management compared to some other fields. It is of great importance to increase awareness of hand-held LiDAR and mobile LiDAR technologies and analyze the benefits they can bring to existing and future building management systems. Therefore, this article aims to investigate the potential applicability of handheld LiDAR systems to benefit building management, enable indoor mapping, and make an application that can assist various disciplines such as mapping, architecture, construction, and archeology.

In this study, a portable hand-held LiDAR-based scanning system in ZEB-REVO provided by GeoSLAM ${ }^{\mathrm{T}}{ }^{\mathrm{M}}$ was analyzed. A deformed building was chosen as the data set. However, the proposed methodology is research that can be adapted to other data sets. In this way, it is possible to extract geometric features of indoor mapping and designs.

\section{MATERIAL AND METHOD}

In this study, a semi-automatic methodology was developed to produce indoor mapping processing from point clouds obtained with GeoSLAM ZEB-REVO. The process flow applied for this is given in Figure 1. Indoor scanning operations were carried out by starting outside the venue.

In order to evaluate the accuracy potential of the hand-held LiDAR according to manual reference data, the point clouds were first cleaned of the noise parts. False points originating from several surfaces in the ZEB-REVO point cloud should be eliminated by statistical method. The precise extraction of the walls is the main goal. Hence, in the performance evaluation, the error rates of the areas calculated with only the building facade planes were evaluated. 

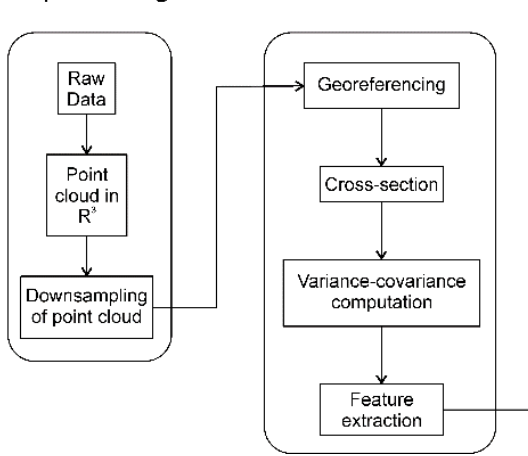

Figure 1. Methodology

\subsection{GeoSLAM ZEB-REVO}

The hand-held LiDAR scanning system for 3D mapping with the principle of SLAM algorithm is a scanner system widely used among portable scanners. Therefore, the ZEB-REVO scanner produced by GeoSLAM was applied in this study for the 3D mapping solution. The solution to the indoor mapping and positioning problem occurs independently of global positioning satellite systems (GNSS) (Shamseldin et al., 2018). The basis of this is a SLAMbased algorithm that is applied iteratively to detailed geometric properties from distance-based profiles in application areas thanks to the continuously moving scanning sensor (Bauwens et al., 2016; James \& Quinton, 2014). The system also includes an inertial measurement unit (IMU) containing triaxial gyroscopes, accelerometers, and triaxial magnetometers (Sammartano \& Spanò, 2018).

ZEB-REVO has the Hokuyo ULM-30LX F type scanner (Dewez et al., 2017) and rotates a 360-degree angle perpendicular to the scanner's handle, increasing data collection capacity (Figure 2). It produces 42300 effective signals per second with an angular range of $0.006 \mathrm{rad}$; that is, it has the capacity to generate 1 point every $6 \mathrm{~mm}$ at a distance of $1 \mathrm{~m}$ with a single signal transmission on a suitable reflection surface. This system may appear sparse in point density compared to high-resolution terrestrial laser scanner systems, but the coverage and density of the point cloud also increase in terms of mobile data collection indoors.

The maximum distance of the scanner is indicated as 30-m indoors (ZEB-REVO, 2019). For outdoor areas, it can collect data at intervals of 15-20 $\mathrm{m}$. The main reason for this is that the surfaces cannot reflect the signals well outdoors. In addition, the issue of noise, which is common in LiDAR systems, is important in point cloud data. In indoor scans, point clouds are also affected by noise: noisy sections can form small clusters. These small clusters of noise cause errors in the production of the building information model, especially on wall surfaces. Since point clusters away from surfaces are not connected to surfaces, their deletion is solved by different algorithms.

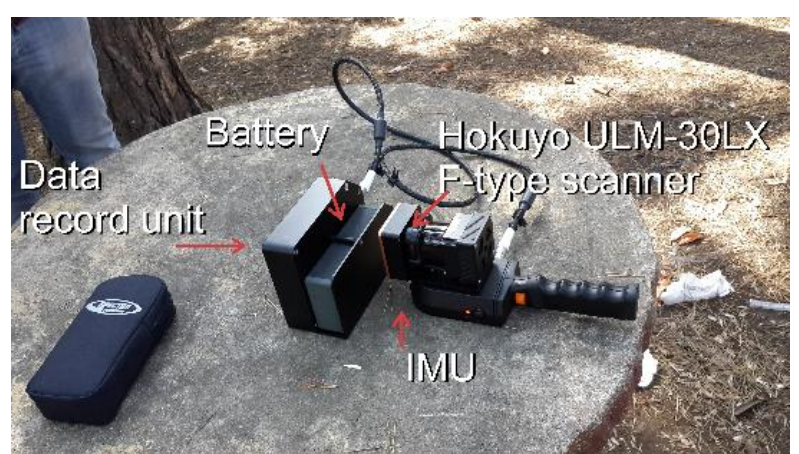

Figure 2. GeoSLAM ZEB-REVO laser scanner system components

\subsection{Point Cloud}

Scanning is more straightforward with the handheld LiDAR system than with typical terrestrial laser scanning systems. The scanning process was carried out by walking freely within the place where mapping of the hand-held device was requested and obtaining 3D spatial information about walls and other objects. There is no need to interrupt the scanning process. Continuous provision of data offers the opportunity to use visions obtained from different perspectives. Alignment is not required after field measurements like in terrestrial laser scanning systems. Particularly after the measurement is finished for the preprocessing of the raw data, the device is a complete point cloud (GeoSLAM Hub Desktop), that is, millions of points in 3D space representing the scanned space (X: $0, Y: 0, \mathrm{Z}: 0$ ) is obtained in the cartesian (rectangular) coordinate system. The point cloud obtained with the inspection area is given in Figure 3. Since the point clouds collected in this study do not require a geodetic coordinate system, they are not transformed to a national reference network and studied in a relative coordinate system. However, if spatial data related to the national reference coordinate system are requested, absolute reference coordinates can be brought to geodetic reference coordinates (georeferencing) in a controlled way with a minimum of four points. For this reason, this stage has been included in the workflow.

In order to extract the relevant floor plan from the point clouds, the cross-section is taken by filtering the point clouds between certain heights, and the building plan extraction processes are started. Section location and thickness may vary according to the feature of the point cloud data and the situation of the space. However, it is more appropriate to take sections at certain distances from the sections where the floor and ceiling points are located. If this region is determined correctly, the histogram graph of the height component distributions of the point clouds should be monitored. Since the floor and ceiling points are closer to the scanning device, this causes more intense data to be produced on these surfaces (Figure 3). 

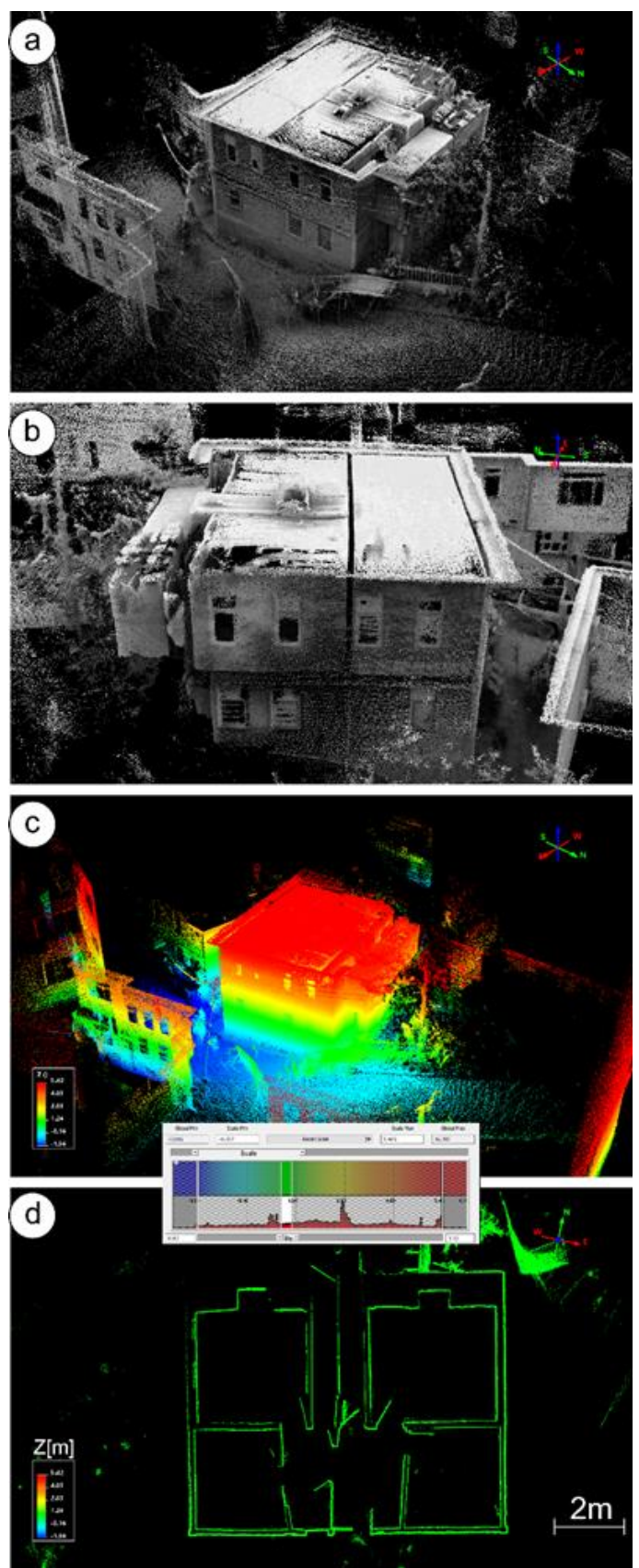

Figure 3. Point clouds obtained with GeoSLAM ZEBREVO, a) building front perspective view, b) perspective view from the rear (deformed) part of the building, c) point clouds colored with relative height values $(-1.56-5.42 \mathrm{~m})$, d) sample test section of $30 \mathrm{~cm}$ thickness and between 0.82 and $1.12 \mathrm{~m}$.

After the cross-section points are achieved, the surface points should be eliminated from noise and distortion. Thus, statistical noise filtering and moving least-squares surface algorithms were applied (Alexa et al., 2003; Rusu, 2010). The presence of noisy points appears to be a significant problem in processing automated 3D point cloud data (Nurunnabi et al., 2015). The moving least-squares surfaces algorithm is defined as an algorithm for reconstructing the discontinuous and irregular point cloud with continuous functions by calculating the weighted least squares method according to the region around the point for estimating the reconstructed value (Alexa et al., 2003).

\subsection{Computation of Locally-Based Eigenvalue Properties}

Variance-covariance matrix ( $C$ ) was calculated according to the local neighborhood value through point clouds. The covariance matrix was calculated with the following formulas to reveal each point's shape $\left(p_{i}\right)$ in the point cloud and its correlation with its neighbors.

$$
\begin{gathered}
\bar{p}=\frac{1}{k} \sum_{i=1}^{k} p_{i} \\
C=\frac{1}{k} \sum_{i=1}^{k}\left(p_{i}-\bar{p}\right)\left(p_{i}-\bar{p}\right)^{T}
\end{gathered}
$$

where $p_{i}$ is associated with $k$ adjacent points around it, $\bar{p}$ represents the average value of $k$ adjacent points for each axis. The covariance matrix $C$ is computed to be centered on the $p_{i}$ point. Eigenvalues $\lambda_{1}>\lambda_{2}>\lambda_{3}$ are used as features. However, these properties were used to determine a plane, edge, and corner properties. Thanks to these eigenvalue-based properties, the characteristics of the $3 \mathrm{D}$ point clouds could be defined. The formula given below shows the computation of the flatness property with eigenvalues.

$$
P_{d}=\frac{\lambda_{2}-\lambda_{3}}{\lambda_{1}}
$$

With the help of eigenvalues and eigenvectors, different criteria can be obtained to calculate each point's characteristics connected to many neighboring points (Fengguang \& Xie, 2017; Weinmann et al., 2013). R programming language codes were used in feature extractions (Team, 2020).

\subsection{Region Growing Algorithm}

The region-growing algorithm is widely used as an image processing operator (Ketenci, 2011; Sümer \& Türker, 2013). Following feature extraction in 3D point clouds data, this study is used to define building walls from each other by surface normals and angular deviations. This algorithm has been applied in order to segment the building walls into sub-groups of large and combined regions according to certain parameters.

In point clouds, surface normals and curvature properties are widely used for grouping (Rabbani et al., 2006). The basic principle of this algorithm ensures that a selected point is assigned to the same group if the criteria for neighboring points are below the threshold values determined by the user. In this study, thanks to this algorithm, the building walls are divided into regions using curvature and surface normals.

In short, the region growing algorithm makes groupings according to the threshold value for determining the similarity properties. The user must give the threshold value, or the process should be started with the pre-group values given as seeds. The 
threshold value can be determined by examining the deviation value between the property values of the region seed points and their neighboring points. With the deviation value below the threshold value, the region grows, and if the value is greater than the threshold value, a new region definition is realized. The number of regions does not need to be given by the user from the prior.

\subsection{Conversion Point Clouds to Raster Data}

In this section, 2D information extraction has been performed by transforming $3 \mathrm{D}$ data into 2D data. For this purpose, dense point clouds defined in 3D space according to point cloud properties and height value were converted into raster data format with $3 \mathrm{~cm}$ resolution. CloudCompare open-source software was used to implement this process (Girardeau-Montaut, 2019). 3D point cloud data provides sufficient information for many goals. However, given the size of the data and tools available to process large volumes of point data, it can be said that working with these data is more difficult, and 2D information extraction is not effective.

Raster or gridded regular data can contain certain properties and values in different bands within a certain cell or pixel ranges on a map (Karakaş \& Türker, 2019). The value in each cell represents an area on the true Earth's surface if it has been spatially georeferenced. Raster data consists of a regular grid network of the same size. The closest data type to the raster data format is images. However, raster data are more advantageous because they do have spatial information. The grid intervals in the raster data that is the resolution value determine the fineness of the detail that can be detected on the ground. Knowing the surface density of LiDAR point clouds, sampling intervals, and wall thickness in advance will aid the calculation of the raster resolution parameter that should be determined in this process.

\subsection{Extraction of Edges from Raster Data}

In this section, edge features in each pixel are calculated on the produced raster data. For this purpose, Orfeo ToolBox open-source software and $\mathrm{R}$ programming language were used (Grizonnet et al, 2017; Team, 2020). The input data was selected as raster data. The data in which the properties are calculated is the image obtained from the raster data. An image containing edge elements, edge features are processed by all three methods (slope/gradient, Sobel, and Touzi). The gradient filter calculates the gradient size of the image for each pixel. The Sobel filter uses the Sobel operator to calculate the image gradient and then finds the magnitude of this gradient vector. The Touzi filter is more suitable for radar images. It has a positional parameter to prevent speckle-noise perturbation. The greater the radius applied, the less sensitive the filter to speckle noise. The results obtained on raster images are given in Figure 4.
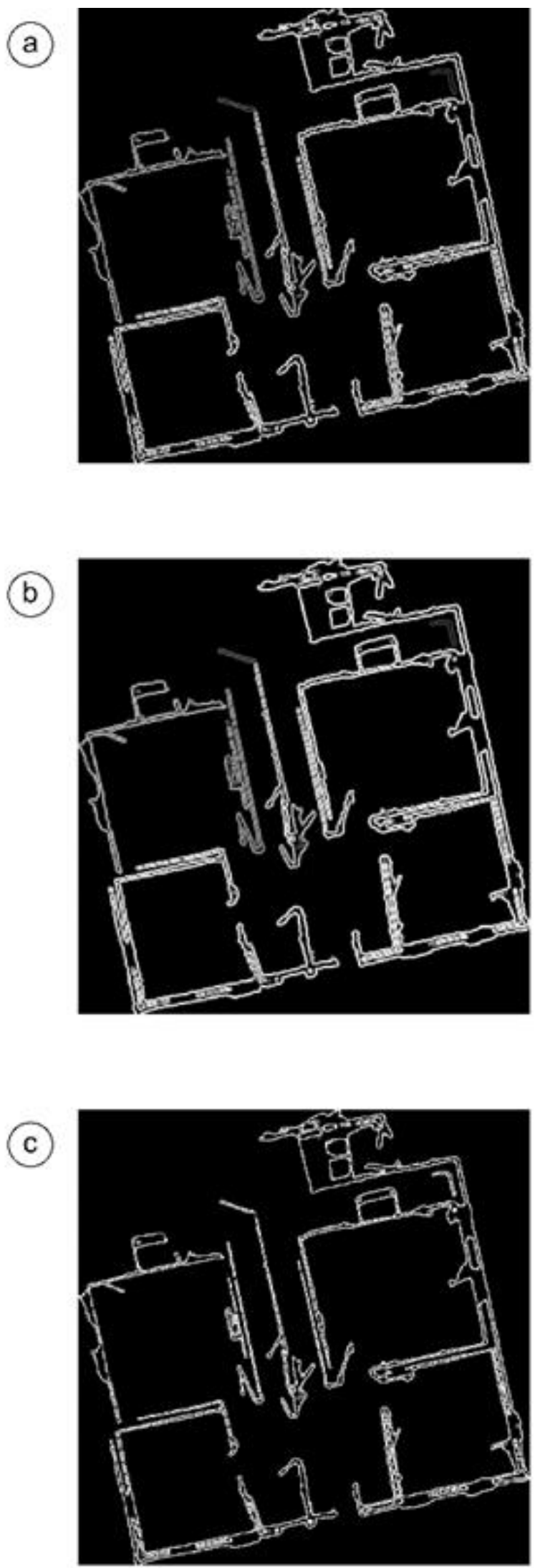

Figure 4. The results of the edge extraction algorithms to derive the layout of the indoor space, a) gradient, b) Sobel, c) Touizi filters.

In order to define the side and interior walls in indoor environments through raster-based data, the boundaries of the relevant objects must be determined. Edge detection or edge extraction 
algorithms constitute one of the most important research issues by computer vision and image processing societies. Height, flatness, curvaturebased values in raster data reveal distinct transitions in raster data, and these changes are revealed by edge detection algorithms of cells representing object objects or wall edges. In the literature, edge detection algorithms are widely used on this subject. Grayscale image processing and analysis and many algorithms in the literature form the basis of these studies (Aybar, 2008).

For raster data, gradients along both the $\mathrm{x}$ and $\mathrm{y}$ axes are obtained as two components. To be more specific, with mathematical notations, the image density $I(x, y)$ is obtained at the $\mathrm{x}, \mathrm{y}$ position and with the following estimates:

$$
\begin{aligned}
& g_{x}=\frac{\partial}{\partial x} I \\
& g_{y}=\frac{\partial}{\partial y} I
\end{aligned}
$$

where it provides information about how fast the gradient values change at each $\mathrm{x}, \mathrm{y}$ location relative to its surroundings. Inferred edges are predicted due to sudden changes in the images, and their positions are estimated according to the gradient norm. The gradient size is formalized as the following equation,

$$
\sqrt{g_{x}^{2}+g_{y}^{2}}
$$

The image processing stage was applied with the help of R commands and the imager package, and the results are given in Figure 5.

\subsection{RANSAC Algorithm Application}

In this section, the estimation of plane parameters on points with the high planar feature is performed using the RANSAC algorithm. RANSAC provides an iterative estimation of plane parameters from points according to the minimum number of points and certain threshold values (Güler, 2018; Karslı \& Pfeifer, 2012; Sevgen et al., 2018). The determination of the planar feature of the crosssection points before the RANSAC algorithm application increased the process performance and the accuracy of the estimation parameters. The fundamental principle of the RANSAC algorithm randomly selects the point with the minimum requirement for the model to be estimated and calculates the deviation of the other points to this model. According to the threshold values, it is determined which other points will participate in this model or not (Fischler \& Bolles, 1981).
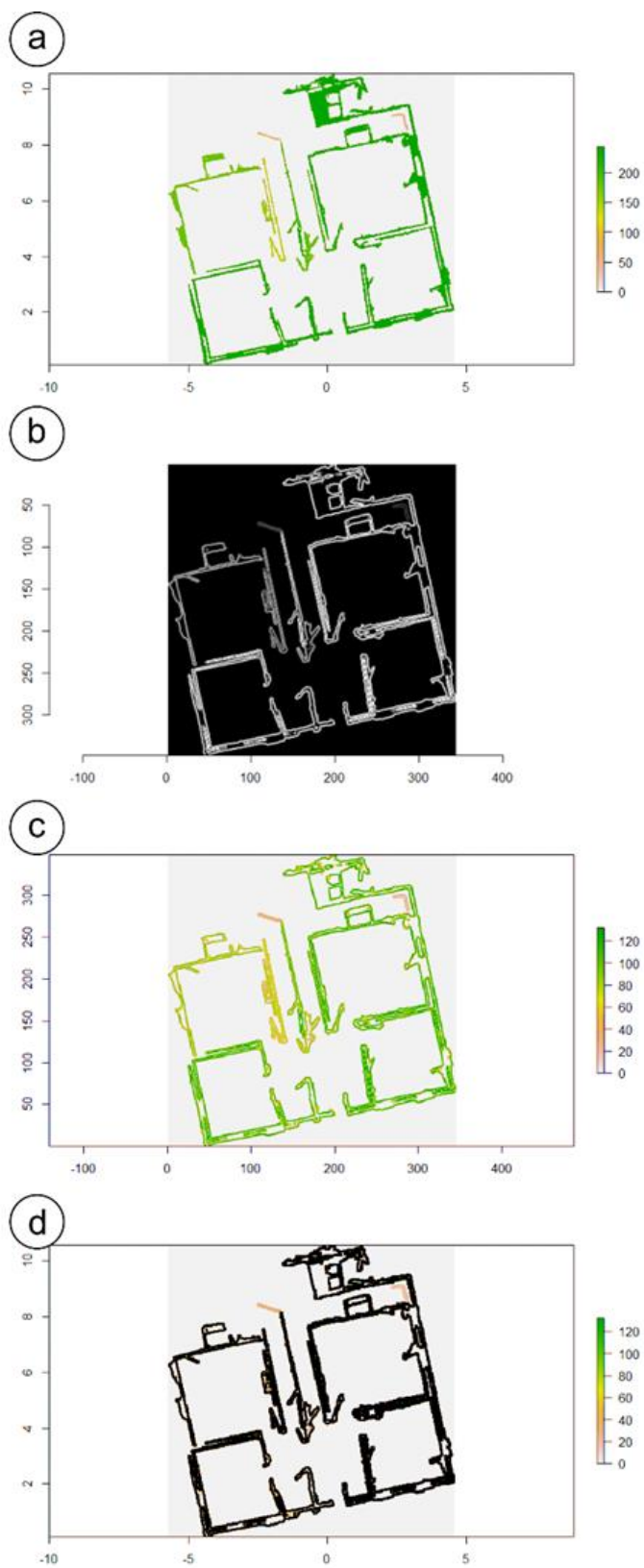

Figure 5. Raster data-based gradient calculations a) height-based raster data, a) image grayscale value, b) conversion raster data to image and calculating gradient c) reconverting the image back to raster data, d) displaying the derived edge lines on raster data.

\section{RESULTS AND DISCUSSION}

In the study, 7 minutes of LiDAR field measurement was carried out, and a total of 11580016 points were acquired. After manual extraction of the single building feature from the produced points, 9818730 points represented the building. Then, the cross-section was applied, and the number of points was reduced to 85542 points. Local characteristics are computed on these points (Figure 6). Figure 6 shows that effectively eliminated the points that are not connected with the connected components algorithm. However, it is still seen that it is very challenging to filter some object points on the wall surface or close to the side surface. 


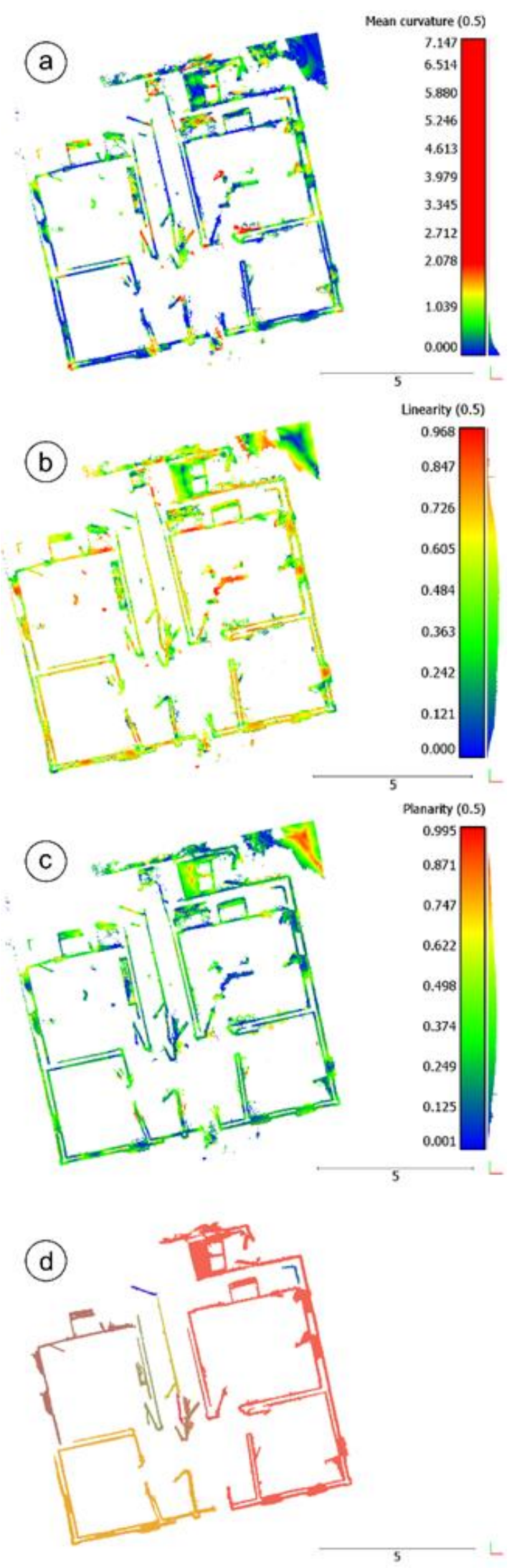

Figure 6. The results of the algorithms applied on the sectioned point clouds, a) mean curvature, b) linearity, c) planarity, d) extraction of walls after analysis of connected point groups.
Figure 7 shows the result of the edges derived after the feature extraction, the application of the connected component algorithm, the manual drawing process by the operator, and the proposed methodology. As it can be understood from here, the produced edges were found effectively, but the objects in the area, especially on the door and wall, could not prevent the methodology's process of finding edges in these areas. In addition, the doors in the area were determined and not drawn by the operator, but the proposed methodology did not separate and eliminate them because of high planarity and adjacent to the wall.

To check the overall metric quality of ZEB-REVO point clouds, their reliability is first performed according to single period/pass measures. The first statistical parameter that comes to mind in evaluating the general reliability is accuracy, and in comparisons made with some surfaces or point clouds derived from more precise measurement systems, it is widely used to examine the deviation of the calculated point clouds with the RMSE value (Zeybek, 2019). However, this study focused on edge extraction integrity and areal accuracies rather than accuracy of measurement data.

Edge extraction with image processing algorithms in raster-based edge extraction provided detailed acquisition of details, but such algorithms were highly affected by the noise of the surfaces and caused the noisy edges extraction. After the application of these algorithms, it has been seen that it is important to integrate further simplifying and orthogonalization algorithms on it.

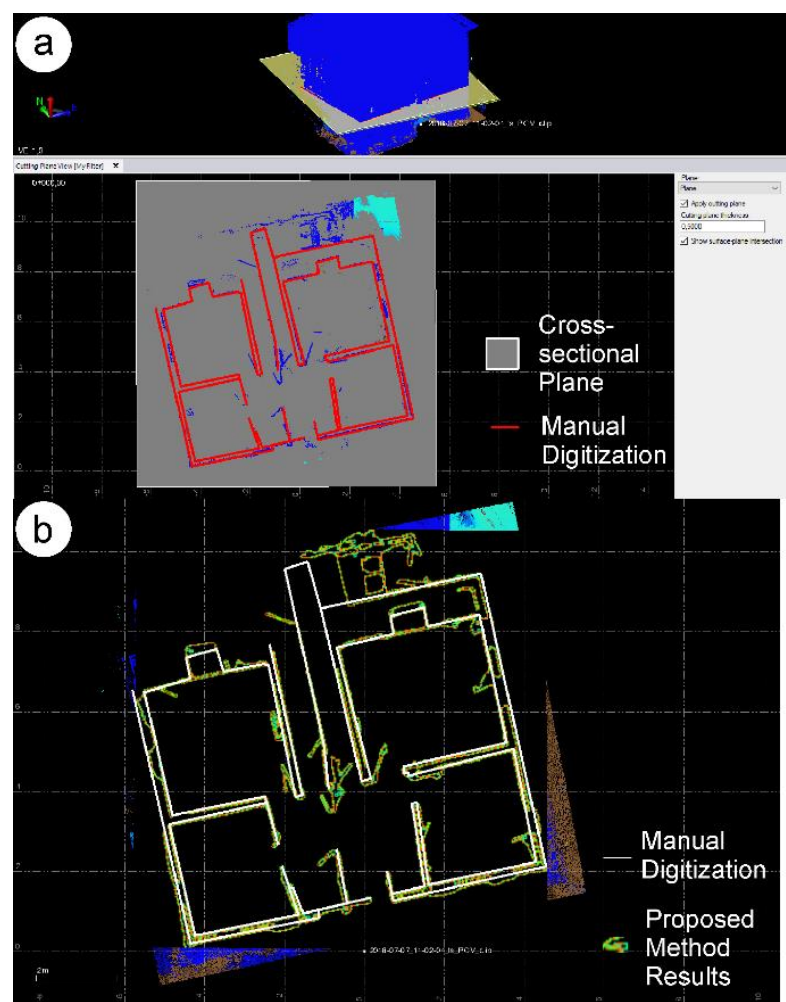

Figure 7. After section and feature extraction, a) manual drawing with CAD program, b) overlay results of manual drawing results with the proposed methodology. 
(a)

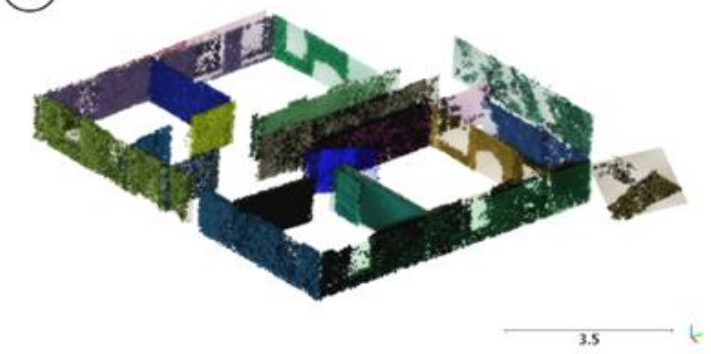

(b)

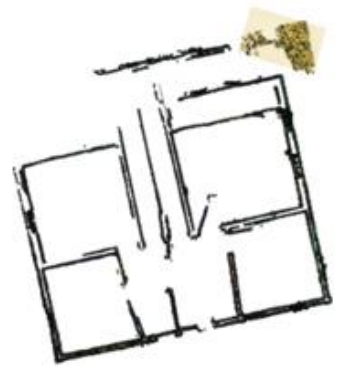

Figure 8. Plane points determined as a result of RANSAC algorithm, a) perspective view, b) top view.

RANSAC application results are shown Figure 8. A minimum of 500 points was chosen to obtain this model. The limit value of the distance to the estimation model is given as $5.5 \mathrm{~cm}$. The point sampling interval is $11 \mathrm{~cm}$. With the predicted plane normal, the maximum angular deviation is 25 degrees.

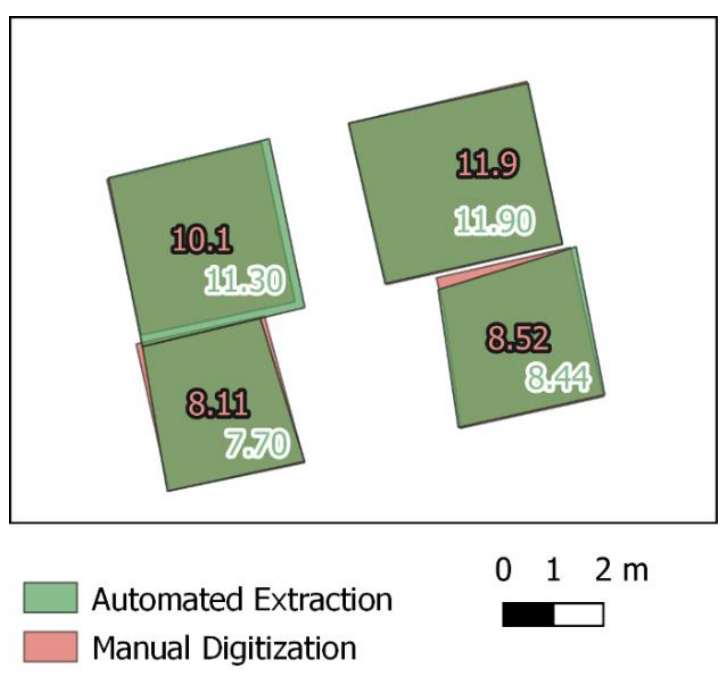

Figure 9. Indoor plans are drawn automatically and with the operator's help (the areas are given in the $\mathrm{m}^{2}$ unit).

The total area of the four rooms of the building is $38.63 \mathrm{~m}^{2}$, and this value was obtained from the plans drawn manually with the help of the operator. The areas determined on the plan automatically created from RANSAC planes were determined as $39.34 \mathrm{~m}^{2}$ (Figure 9). The relative error rate was found to be $1.8 \%$. The main reason for the high error rate is thought to be due to the low planar rates in the interior walls. Besides, some walls were scanned from outside, and some parts were not scanned, which caused a decrease in accuracy in-plane estimation.
In order to improve the results of the study, it has been concluded that future studies should focus on the following issues: improvement of surface normals in the determination of sidewalls, determination of wall intersection directions well and firmly. To improve area drawings, corner points can be determined, and automatic area calculations can be made, and thus, the extraction of fully automatic building plans can be improved. By creating circumstances to obtain only vertical planes, horizontal planes that may occur indoors can be avoided.

\section{CONLUSIONS}

The purpose of this article is to present a comprehensive approach for indoor mapping and localization of plans, thanks to the 3D spatial essential knowledge of point clouds obtained with a hand-held LiDAR scanning system. The basic structure of the applied methodology is on the geometric extraction of 2D data from the 3D point cloud data and the analysis of the outcomes. Precise mapping of indoor areas is complex and rather difficult under various situations. Thanks to the point clouds obtained with the handheld LiDAR scanning system, dense spatial information was obtained, and spatial mapping application was shown on a specific test area with the applied sequential algorithms. The results obtained may differ slightly when compared to reference data or when compared to other LiDAR systems. In addition, differences in the distribution, the density of the generated point clouds, laser scanning pattern, size of the area, or any other environmental conditions can affect the results. Also, it has been observed that the inexperience of a surveyor in certain data negatively affects the production of basic structures. For this reason, it has been observed that it is important to make field measurements by experienced, expert and qualified, and competent people. For future studies on this topic, improvements should focus on two main issues. First of all, it is important to develop a standard data collection technique for data acquisition and to be able to view all walls, especially in point clouds. This situation can be reduced by displaying the SLAM technology simultaneously on the screen. However, applying geometric shapes and standards in data collection may still be a solution to this problem. The second issue is that the 2D wall information needs to be further improved with edge extractions, and its robustness should be increased. For this, optimizing the line feature extraction with a segmentation application will provide important convenience. Finally, it is not easy to convert indoor locations, especially complex areas, to 2D data automatically today. The main reasons for this are directly related to the basic improvements stated in the above paragraphs. However, it is also possible to improve the results by developing the methods suggested in this article, and it is inevitable to work on robust and fully automated line extraction in future studies. 


\section{ACKNOWLEDGMENT}

The author thanks Geomatics Group Surveying company and Survey Engineer Melih Ergün for measuring and sharing the data used in the study.

\section{REFERENCES}

Alexa M, Behr J, Cohen-Or D, Fleishman S, Levin D \& Silva C T (2003). Computing and rendering point set surfaces. Ieee Transactions on Visualization and Computer Graphics, 9(1), 315. doi:10.1109/Tvcg.2003.1175093

Aybar E (2008). Sobel işleci kullanılarak renkli görüntülerde kenar bulma. Afyon Kocatepe Üniversitesi Fen Ve Mühendislik Bilimleri Dergisi, 8(1), 205-217.

Bauwens S, Bartholomeus H, Calders K \& Lejeune P (2016). Forest Inventory with Terrestrial LiDAR: A Comparison of Static and HandHeld Mobile Laser Scanning. Forests, 7(12). doi:10.3390/f7060127

Dewez T J B, Yart S, Thuon Y, Pannet P \& Plat E (2017). Towards cavity-collapse hazard maps with Zeb-Revo handheld laser scanner point clouds. The Photogrammetric Record, 32(160), 354-376. doi:10.1111/phor.12223

Fengguang X \& Xie H (2017). A 3D surface matching method using keypoint- based covariance matrix descriptors. Ieee Access, 5, 1420414220. doi:10.1109/ACCESS.2017.2727066

Fischler M A \& Bolles R C (1981). Random sample consensus: a paradigm for model fitting with applications to image analysis and automated cartography. Commun. ACM, 24(6), 381-395. doi: $10.1145 / 358669.358692$

Girardeau-Montaut D (2019). Cloudcompare GPL software verison 2.10. Erişim Linki https://www.danielgm.net/cc/. Erişim tarihi: 08 December 2020

Gopi S, Sathikumar R \& Madhu N (2018). Adavanced Surveying, Total Station, GPS, GIS and Remote Sensing.

Grizonnet M, Michel J, Poughon V, Inglada J, Savinaud M \& Cresson R (2017). Orfeo ToolBox: open source processing of remote sensing images. Open Geospatial Data, Software and Standards, 2(1), 15. doi:10.1186/s40965017-0031-6

Güler M (2018). Lidar Verisinden Bina Çatı Düzlemlerinin Otomatik Çıkarımı ve Modellemesi. Hacettepe Üniversitesi, Ankara.

James M R \& Quinton J N (2014). Ultra-rapid topographic surveying for complex environments: the hand-held mobile laser scanner (HMLS). Earth Surface Processes and Landforms, 39(1), 138-142. doi:10.1002/esp.3489

Karakaş G \& Türker M (2019). Yüksek Çözünürlüklü Ortofoto ve Lidar Verisinden Hough Dönüşümü ve Algısal Gruplama Kuralları ile
Bina Sınırlarının Çıkarımı. Afyon Kocatepe University Journal of Sciences and Engineering, 19(3), 716-731. doi:10.35414/akufemubid.559183

Karasaka L (2012). Mobil yersel lazer tarama sistemlerinin fotogrametrik rölöve projelerinde kullanılabilirliği üzerine bir çalışma. (Doktora). Selçuk Üniversitesi Konya.

Karslı F \& Pfeifer N (2012). Ransac Algoritması ile Lidar Verilerinden Otomatik Detay Çıkarımı. Paper presented at the IV. Uzaktan Algilama ve Coğrafi Bilgi Sistemleri Sempozyumu (UZAL-CBS 2012), Zonguldak.

Ketenci S (2011). Otomatik tohumlandırmalı bölge büyütme metoduyla renkli görüntülerde bölge ve kenar tespiti. (Yüksek Linsans). Karadeniz Teknik Üniversitesi, Trabzon.

Nurunnabi A, West G \& Belton D (2015). Outlier detection and robust normal-curvature estimation in mobile laser scanning 3D point cloud data. Pattern Recognition, 48(4), 14041419. doi:10.1016/j.patcog.2014.10.014

Rabbani T, Van Den Heuvel F \& Vosselmann G (2006). Segmentation of point clouds using smoothness constraint. International Archives of Photogrammetry, Remote Sensing and Spatial Information Sciences, 36(5), 248253.

Rusu R B (2010). Semantic 3D object maps for everyday manipulation in human living environments. KI - Künstliche Intelligenz, 24(4), 345-348. doi:10.1007/s13218-0100059-6

Sammartano G \& Spanò A (2018). Point clouds by SLAM-based mobile mapping systems: accuracy and geometric content validation in multisensor survey and stand-alone acquisition. Applied Geomatics. doi:10.1007/s12518-018-0221-7

Sevgen S C, Karslı F \& Pfeifer N (2018). Lidar Verisinden Otomatik Bina Çatı Düzlemi Clikarmada Ransac Algoritmasının Iyileștirilmesi. Paper presented at the VII. Uzaktan Alglama-CBS Sempozyumu (UZALCBS 2018), Eskişehir.

Shamseldin T, Manerikar A, Elbahnasawy M \& Habib A (2018). SLAM-based Pseudo-GNSS/INS Localization System for Indoor LiDAR Mobile Mapping Systems. 2018 Ieee/Ion Position, Location and Navigation Symposium (Plans), 197-208.

Sirmacek B, Shen Y, Lindenbergh R, Zlatanova S \& Diakite A (2016). Comparison of Zeb1 and Leica C10 Indoor Laser Scanning Point Clouds. ISPRS Annals of Photogrammetry, Remote Sensing and Spatial Information Sciences, III-1, 143-149. doi:10.5194/isprsannals-III-1-143-2016

Sümer E \& Türker M (2013). Cephe dokularının tekli yersel bina görüntülerinden bölge büyütme tabanlı bir yaklaşım kullanılarak otomatik 
çıkarımı. Jeodezi ve Jeoinformasyon Dergisi(107), 49-57.

Team R C (2020). R: A Language and Environment for Statistical Computing. Erişim Linki https://cran.r-project.org/. Erişim tarihi: 21/04/2021

Velas M, Spanel M, Sleziak T, Habrovec J \& Herout A (2019). Indoor and Outdoor Backpack Mapping with Calibrated Pair of Velodyne LiDARs. Sensors, 19(18). doi: $10.3390 / \mathrm{s} 19183944$

Weinmann M, Dittrich A, Hinz S \& Jutzi B (2013). Automatic Feature-Based Point Cloud Registration for a Moving Sensor Platform. Isprs Hannover Workshop 2013, 40-1(W-1), 373-378.
Yadav M \& Singh A K (2018). Rural Road Surface Extraction Using Mobile LiDAR Point Cloud Data. Journal of the Indian Society of Remote Sensing, 46(4), 531-538. doi:10.1007/s12524-017-0732-4

ZEB-REVO (2019). GeoSLAM ZEB-REVO. Retrived From https://geoslam.com/solutions/zebgo/. Access Date: 6 Nisan 2021

Zeybek M (2019). El-tipi LiDAR ölçme sistemleri ve 3B veri işleme. Türkiye Lidar Dergisi, 1(1), 10 $-15$. 